\title{
Emberséget és tudományt tanultunk töle Emlékezés Szathmári Istvánra, a Tanárra
}

\section{Bevezetés}

Az elmúlt esztendő őszén, 2020. november 3-án, életének 96. évében elhunyt Szathmári István professzor, a magyar nyelvtudomány, a stilisztika meghatározó alakja, iskolateremtő egyénisége. Nyelvészek és tanárok nemzedékeinek szeretett és mélyen tisztelt Szathmári tanár ura. Az őszi-téli járványhelyzetben munkatársai és tanítványai közül csak néhányan kísérhették el utolsó földi útján, csak lélekben és gondolatban vehettünk búcsút tőle. Szathmári tanár úr értékes örökséget hagyott ránk. Tudósi és tanári munkássága, pedagógiai hatása egyedülállóan gazdag és sokrétü. Érdemes, sőt szükséges továbbvinni és kamatoztatni.

„Tulajdonképpen emberséget és tudományt tanultunk töle” - írta ezt ő maga saját mesteréről, Bárczi Gézáról (Szathmári 1998: 5). Mi is ezt tanultuk Szathmári tanár úrtól, ezt adta nekünk tovább. Most, amikor erre a megtisztelő, de nehéz feladatra készültem, hogy arról írjak, milyen volt Szathmári István, a tanár, újra és újra átgondoltam, mit is tanultam én töle. És ha egy mondatban kellene megfogalmaznom a választ, ennél jobban és igazabban nem tudnám: emberséget és tudományt tanultam tőle. S bár nem egyeztettem most másokkal, de azt hiszem, nyugodtan, sőt biztosan mondhatom többes számban, sokunk nevében: emberséget és tudományt tanultunk töle.

Ennek a tanulási folyamatnak a jellegét és néhány állomását kívánom emlékezésemben fölidézni, elöre bocsájtva, hogy a pedagógiában és a pedagógiai hatásban legfontosabb az egész, a teljesség, a teljes ember, a teljes és kölcsönös emberi viszonyulás, a személyes hitelesség és a példaadás. Megnyilvánulási módja pedig minden életkorban, minden életszakaszban más-más, formája a közös munka, kerete pedig a munkaközösség.

\section{A tudomány és a tanítás szolgálatában}

Szathmári István több mint hét évtizedes tudományos és pedagógiai tevékenységét, gazdag pályájának eredményeit most meg sem kísérelem összefoglalni. Munkásságát az életút egyes állomásain bemutatták munkatársai, több alkalommal is. Ezekre az összefoglalásokra, értékelésekre utalva, pár mozzanatukat kiemelve jelzem, hogy Szathmári professzor úrról, a tanárról lehetetlen szólni a nyelvtudós méltatása nélkül. Hiszen a kettő, a nyelvtudós és a tanár természetesen egy, egyik erősíti a másikat, másik az egyiket, együtt adják az egészet.

1995-ben a Magyar Nyelvtudományi Társaságban Keszler Borbála köszöntötte a 70 éves Szathmári Istvánt, méltatta addigi tudományos és pedagógiai tevékenységét az ünnepelt tiszteletére készült kötetben is (Keszler 1995). Egy évtizeddel később, ugyancsak a Társaságban Balázs Géza jellemezte az akkor 80 éves Szathmári István sokoldalú tevékenységét, tanári, alkotói és tudományszervezői aktivitását 
(Balázs 2005). Ekkor jelent meg a munkatársak által összeállított újabb kötet, a Szükebb és tágabb haza nyelve, amely Tanár úr népnyelvi és irodalmi nyelvi tanulmányait tartalmazza, régi nyelvtanainkkal, a nyelvi egységesüléssel, a nyelvi norma alakulásával foglakozó munkáival együtt (Szathmári 2005). Majd pedig 2015-ben a Nyelvtudományi Társaság ünnepi ülésén, az ELTE zsúfolásig megtelt Tanácstermében köszönthettük a 90 éves Szathmári tanár urat. Itt mutatta be frissen megjelent tudománytörténeti munkáját, szeretett szakmai közössége, a Magyar Nyelvtudományi Társaság történetét feldolgozó könyvét (Szathmári 2015), és a tőle megszokott derüvel vázolta fel további terveit.

És mint tudjuk, dolgozott, publikált tovább. Például itt, folyóiratunk, a Magyar Nyelvőr hasábjain is: Dayka Gábor nyelvészeti munkáiról írott két tanulmányát a korszak kutatásában a későbbiekben nem lehet figyelmen kívül hagyni (Szathmári 2018, 2019). A páratlanul gazdag és sokoldalú életmü az elmúlt évben emberileg, fizikailag lezárult, de tudományos értéke és hatása él, velünk maradt.

\section{A tanítványok széles köre}

3.1. Most, amikor ebben a különös, járványos időszakban személyes találkozásokban nem lehetünk együtt, legfeljebb csak a virtuális térben, magunkban, lélekben és gondolatban emlékezhetünk. Így emlékezem én is Szathmári tanár úrra. Felidézem, diákéveimet, vizsgáimat, pályakezdésemet, a Stíluskutató csoport összejöveteleit, a szakmai rendezvényeket, beszélgetéseket, és hálás szívvel gondolok mindarra, amit kaptam, amit - többes számban mondom - kaptunk töle. Nyelvi és irodalmi ismereteket, a nyelvtudomány és a munka tiszteletét, a stilisztika szeretetét, de mindenekelött szemléletmódot, az ember, a másik ember, a közösség, a szükebb és tágabb haza népének és nyelvének a megbecsülését.

3.2. De bizonyára nem csak mi, közvetlen tanítványai és munkatársai érezhetjük ezt így, hanem sokan mások is, közelebbi, távolabbi kollégák, hiszen a Tanár úr magyartanárok, nyelvészek és irodalmárok nemzedékeit oktatta, tanította, nevelte filológiai igényességre, az értékek tiszteletére és megbecsülésére, hét évtizeden át. Tudjuk, hogy 1948-tól kezdve tanított, előbb Debrecenben, majd az ELTE Magyar Nyelvtudományi Tanszékén, itt tanárként, tanszékvezetőként, dékánként is teljesítette feladatát. Közben vendégtanár volt Helsinkiben, később tanított még rendszeresen a Kodolányi János Főiskolán is. És tanított akkor is, amikor előadásokat tartott szerte az országban és külföldön, konferenciákon, anyanyelvi rendezvényeken, versenyeken, ünnepi és hétköznapi alkalmakon. Tanárok és diákok őrzik magukban és idézik föl a győri kiejtési, a sátoraljaújhelyi nyelvhasználati, az egri és a gyulai helyesírási versenyek meg konferenciák emlékét, Szathmári tanár úr előadásait, biztató szavait. És akkor még nem is említettem a tágabb haza, a Kárpát-medence helyszíneit, Váradot, Kolozsvárt, Nyitrát, Adát meg a további és távolabbi rendezvényeket, amelyekre, míg csak egészsége lehetővé tette, hívásra mindig megérkezett, és előadásával, zsürielnöki tevékenységével hozzájárult a magyar nyelv és kultúra hagyományának és értékeinek tudatosításához, ezáltal fenntartásához, megmaradásunkhoz. 
3.3. De a kör - kiket és hogyan tanított Szathmári tanár úr - még ennél is tágabb. Hiszen nevét nemcsak a szakmabeliek, nemcsak a magyartanárok és a versenyekre eljutó diákok, hanem a rádióhallgatók, tévénézők is megismerték. A Magyar Rádió meg a Duna Televízió nyelvi músorainak gyakori előadója, munkatársa volt. Az anyanyelvi kultúra ügyét, a nyelvmüvelést, a nyelvi ismeretterjesztést mindig fontosnak tartotta, és szolgálta, müvelte. Szakfolyóiratokban, napilapokban, regionális és helyi folyóiratokban vagy éppen az Édes Anyanyelvünk oldalain közölt verselemzéseiben. Mindezeket könyveivel, magyar és idegen nyelvü tanulmányaival egyidejüleg írta és jelentette meg. Fontosnak tartotta, hogy mind tudományos munkáival, mind az ismeretterjesztéssel a lehető legszélesebb olvasóközönséget elérhesse, és hogy írásait, általuk a nyelv és stílus kérdéseit olvasói megértsék. Tanította egész népét, „,nem középiskolás fokon”.

3.4. Szathmári tanár úr szeretett és tudott tanítani, igazi pedagógus volt. De kutatni, a tudományt müvelni, legalább annyira. Erről egy 1976-ban készült beszélgetésben például így írt: „De most is azt vallom, hogy ha még egyszer születnék, akkor is tanító-tanár lennék... Ugyanakkor azonban nem tudom elválasztani a tanítást a tudományos munkától [...] Tehát azt mondhatom: tanítani, tudományosan dolgozni - ez a további életcélom" - fogalmazta meg ezt a számára is fontos teljességet (Szathmári 1998: 7).

3.5. Ahogy a bevezetőben utaltam rá, tanítvány volt ő maga is. Konkrét pedagógiai értelemben, meg ,,amúgy”, magasabb értelemben is. Sok mindent kapott otthon, iskoláiban, sok mindent hozott magával. Munkaszeretetét, erkölcsi tartását, soha meg nem szünő nyitottságát, hagyományőrzését, hazaszeretetét családjából és Kisújszállásról, a református gimnáziumból. Innen, anyanyelvjárásából hozta jellegzetes beszédét is, ahogy ő írt róla: „A kisújszállási embereknek a dallamos hangzású, tisztán és tempósan ejtett, színes, képekben, szólásokban gazdag, tréfára is hajló beszéde a tiszai nyelvjáráshoz tartozik" (Szathmári 1999: 416). A végtelennek látszó, a tekintetet a transzcendenssel közvetlenül összekötő alföldi tágasság meg az ég és föld kapcsolatának, a környezet, a táj megbecsülésének természetességét adhatta számára. A környezet, a külső-belső rend, a tisztaság mindig fontos volt neki, ezt gyakran emlegette, konkrét környezeti és gondolkodásbeli tekintetben is.

A gimnáziumi évek után a tudományos és tanári pályához mesterétől, Bárczi Gézától kapta a közvetlen indítást és az útravalót, amelyre azután nyelvészpályáját építhette, tanári munkáját, pedagógiáját alapozhatta. A debreceni egyetem magyar-német-francia szakos hallgatójaként lett diákja annak a Bárczi-iskolának, amely a későbbi nagy nyelvésznemzedék tagjaival együtt őt is útjára indította. Ebben a munkaközösségben szegődött el életre szólóan a bölcsészet, a filológia, a nyelvtudomány mellett, és hívatott el a nyelv, az irodalom, a kultúra - és mindezeken keresztül - a magyar nyelvközösség, a magyar nemzet szolgálatára. 


\section{Egy volt diák emlékezése}

Szathmári tanár úr - így neveztük, így nevezték őt diákjai, tanítványai, munkatársai, nyelvészek és magyartanárok nemzedékei. Így köszöntöttük, így szólítottuk meg, amikor találkoztunk vele, egyszerüen, de mindig a legnagyobb tisztelettel. Így emlékezem rá most én is. Mint minden emlékezés, ez is szubjektív, elfogult, de tartalmaz olyan elemeket, olyan mozzanatokat, amelyek általánosabban is érvényesek. Azt, hogy milyen volt Szathmári István, a tanár, hitelesen a magam példáján keresztül tudom elmondani, de tudom, mert tanúja voltam, hogy mindaz, amit én tanulhattam tőle, az sok pályatársammal közös.

4.1. Nevét először Pakson, a Vak Bottyán Gimnáziumban hallottam, 1971-ben, negyedikben, az egyik magyarórán, amikor stilisztikáról volt szó. A pesti bölcsészkaron végzett tanárom, Gálosi János említette volt tanárát, Szathmári Istvánt, pontosabban Szathmári tanár urat. Azután nem sokkal később, az évzárón kapott jutalomkönyvem címében láttam leírva is: Szathmári István: A magyar stilisztika útja. Gondolat Kiadó, 1961. Mindennek immár ötven éve. Most, ahogy levettem a polcról, hogy ellenőrizzem a memóriámat, bevillant, hogy hiszen első nyelvészeti szakkönyvemet kaptam meg akkor. Ebben az évben kezdtem meg egyetemi tanulmányaimat az ELTE magyar-orosz szakos hallgatójaként. Tanárom, osztályfönököm, azzal bocsátott utamra, hogy minél előbb keressem meg Szathmári tanár urat, és okvetlenül adjam át neki üdvözletét.

Mindezeket azért idéztem föl most ilyen részletességgel, mert számomra itt kezdődött Szathmári tanár úr pedagógiája, tanári munkájának, hivatásának a hatása. A folytatás már megint csak többekkel közös vagy legalábbis hasonló lehetett: kissé tétova, ugyanakkor várakozásteli szeptember a neves pesti egyetemen, az ismeretlen nagyvárosban, az éppen elkészült (eredetileg munkásszállónak épült) diákotthonban, a Budaörsi úton. Minden ismeretlen, minden új, de hoztam magammal az útravalót, a feladatot: fölkeresni Szathmári tanár urat. Névtábláját először nem is a tanszéken, hanem a dékáni hivatal falán láttam meg, és persze nem volt bátorságom oda „,csak úgy” bekopogtatni, hívás nélkül beállítani. Így azután megnéztem több alkalommal is a táblát, Tanár úr fölkeresését meg halogattam, mígnem segítségemre jött a „véletlen”. A Ménesi úton lakó csoporttársaimtól megtudtam, hogy Szathmári tanár úr nyelvészeti szemináriumot tart - mint később kiderült, jó szokása szerint - az elsőéves Eötvös-kollégistáknak. No, ide a következő héten én is elmentem, és összeszedve minden bátorságomat, bekéredzkedtem az órára. Nem kellett sokat magyarázkodnom (de azért kellett), Tanár úr kisegített, hát maradjak, ha már idáig eljöttem, mondta. (Azt a bizonyos üzenetet csak jóval később volt bátorságom átadni.)

4.2. A szeminárium, a Magyar nyelvészet Eötvös-kollégistáknak, a nyelvészkönyvtár melletti szobában volt, a Pesti Barnabás utcai épületben. Filológiával, folyóiratokkal, majd szótárakkal ismerkedtünk, úgy, hogy a könyvtárban mindent kézbe is tudtunk venni. A bibliográfiai alapok után szótárak bemutatását kaptuk feladatként, nekem Szinnyei József Magyar tájszótára és a „nagy” értelmező szótár egyik kötete 
jutott. Később történeti, jelentésbeli és stilisztikai összefüggéseket kellett keresnem az iromba 'tarka, foltos, pettyes, pettyegetett' meg az otromba 'formátlan, nagy, durva' és a goromba 'érdes, durva, darabos' között. Időt és lehetőséget kaptunk, hogy elmélyedjünk a feladatokban, és hogy gondosan készüljünk fel az órákra. És ott volt mögöttünk könyvtár, meg az este 10-ig nyitva tartó Eötvös-könyvtár.

Kapóra jött nekem ez az iromba, életemben azután többször is. Elöször, amikor édesanyám pár hét múlva otthon megkérdezte, hogy „na, mit tanultál lányom azon a pesti »eggyetemen«". Hát, mit is mondjak gondolkodtam tétován, hogy anyám is értse, hát... szótárakkal meg tyúkokkal foglalkoztam, mondtam, a kendermagos tyúkjainkkal (felénk így hívták az irombát). Édesanyám válaszát nem idézem szó szerint, a lényege az volt, hogy ezér bizony kár volt annyit tanulni, és föleg kár volt olyan messzire, Pestre menni. Az is igaz, hogy az én magyarázatom is gyenge volt, mert az anyám tyúkja, vagyis a saját nyelvi világom és az oly áhított magas tudományosság kapcsolata még akkor bennem sem volt meg egységben, egészben. Legfeljebb csak sejtettem valamit abból, hogy a szavak történetéből, a jelentésváltozásokból, a tájszavakból valami olyasmit tanulhatok, valami olyasmire ismerhetek rá, amelyhez nekem magamnak is van közöm.

Most már tudom, hogy a sötétbe hajló délutánokon (Tanár úr hivatali elfoglaltságai miatt későn voltak az órák, de mindig megvoltak) alapkérdések fölött darvadoztunk, 'mélázva, beszélgetéssel töltöttük az időt' (ez is egyik vizsgált szavunk volt). Nyelv és múlt, nyelv és identitás volt a téma. Köznyelv és nyelvjárások; írás, hangzás, jelentés; nyelv és stílus összefüggéseit tárgyaltuk. Ma már tudom, hogy szótárakat lapozgatva (Kosztolányi szófordulata) valójában filológiát, nyelvtörténetet, stilisztikát, grammatikát tanultunk, és közben azt is, hogy felismerjük, megbecsüljük saját nyelvi világunkat, múltunkat, kultúránkat. Köszönöm ezt ma is Tanár úrnak. Mint ahogy azt is, hogy megkérdezett bennünket gondjainkról, hogy elmondhattuk ügyes-bajos egyetemi, tanulmányi dolgainkat, és hogy biztató szavakat, bátorítást, támogatást kaptunk. Ezek nekem akkor sokat jelentettek, voltak köztük olyanok is, amelyek előkészítették, sőt meghatározták későbbi pályámat. Hogy egy konkrét példát is mondjak ebből az első félévből: nagyon szerettem volna átkerülni az Eötvös-kollégiumba, vonzott a könyvtár, a szakkollégium, a nyelvórák lehetősége, az egyetem és a Duna közelsége, és a második félévben erre, Tanár úr támogatásával, lehetőségem is nyílott. Így azután én is Eötvös-kollégista lettem, és immár ,jogerősen" jártam a szemináriumra.

4.3. A közös mühelymunka, mert a kollégisták csoportjából az lett, később is folytatódott, stilisztikai szakszemináriumokon, szakdolgozati szemináriumokon, újabb és természetesen nem csak kollégiumi hallgatókkal kibővülve. A magyar stilisztika múltja és jelene; A magyar stilisztika útja; Stilisztika; Szakdolgozati szeminárium ezek voltak a tárgyak, mostani néven kurzusok, és egyikük-másikuk több féléven át is folytatódott. A leckekönyvem szerint, most megnéztem, és magam is meglepődtem, nem volt olyan félévem, hogy ne jártam volna Tanár úr valamelyik órájára. Az órákon a hallgatónak nem lehetett csak hallgatnia, nem lehetett nem megszólalnia: beszélni kellett, kérdezni, hozzászólni, véleményt mondani, aktívan jelen lenni. 
4.4. A szakdolgozati szemináriumon például előzetes bibliográfiát kellett összeállítani, abból számos tételt adott időre elolvasni, feldolgozni, majd vázlatot készíteni, fejezeteket megírni, átírni és mindennel határidőre, ahogy mondta Tanár úr, inkább egy-két héttel elébb elkészülni. A szakdolgozati témákban való előrehaladásunkat, „eredményeinket”, kérdéseinket elöbb közösen, hogy mindenki tanuljon belöle, majd egyen-egyenként beszéltük meg. Tanár úr minden reális témaválasztást támogatott, azt is, ha valaki olyan írót, költőt választott, aki az aktuális kánonban nem szerepelt. Készült szakdolgozat akkor a csoportban, ahogy most felidézem, Krúdy stílusáról, kettő is, volt angol-magyar, orosz-magyar szövegstilisztikai tárgyú vagy volt például a hangzó nyelv rádiós változatait vizsgáló szakdolgozó (később rádiós munkatárs) is köztünk.

Szakdolgozati téma lehetett Sinka István költészete is, az én, ugyancsak egyéni témaválasztásom. Sinkáról az Eötvös-kollégiumban az újságíró és riporter Fábián Gyulától hallottam, a népi írókról tartott szemináriumán. Megragadott a fekete bojtárnak, e balladai mélységű, nagyszalontai pásztorköltőnek a stílusa, képi világa, a Sinka-versek tematikája, a költő különös nyelvi érzékenysége, verseinek sok tekintetben számomra ismerős népi atmoszférája. Ezért különösen nagy öröm volt számomra, hogy Szathmári tanár úr a legtermészetesebb módon, magától értetődően vállalta el tervezett szakdolgozati témám vezetését. Sőt még örült is neki, mivel mint később kiderült - ő maga is jól ismerte és nagyra becsülte a népi írókat, köztük is kiváltképpen Szabó Pált, Sinkát meg Illyés Gyulát. Sinka Balladáskönyvére és benne Muhoray Mihály naiv illusztrációira külön is fölhívta a figyelmemet. Szabó Pál prózájának stílusáról, névvilágáról többször is írt (pl. Szathmári 1993), Illyés Gyula verseivel is szívesen foglalkozott, és ő írt utószót Illyés nyelvi írásainak gyüjteményéhez (Szathmári 2002).

4.5. Visszatérve az egyetemi órákhoz, a munka volt a legfontosabb. Ennél csak egy volt még fontosabb, az ember, a másik ember, akkor és ott a hallgató. Kissé más vonatkozásban, de ide kapcsolódóan sejlik föl bennem 1975-ből a kép: ötödéves orosz szakosok leningrádi részképzésen vettünk részt, és éppen Moszkvában töltöttünk egy hetet (a moszkvai csoport meg a mi helyünkön volt Leningrádban). Ültünk, darvadozva, egy étterem különtermében, és hallgattuk a hivatalos látogatóba érkezett Szathmári dékán úr szavait. Elmondta az otthoni híreket, mi meg mondtuk friss élményeinket. Kérdezte, hogy milyen az ellátásunk, miben tudna segíteni, hasznosan telik-e az időnk, és intett bennünket, hogy ne a nehézségeket nézzük, hanem a lehetőségekkel éljünk. Még énekeltünk is, előbb orosz, majd magyar népdalokat, később még zsoltárokat, sőt a himnuszt is. Szathmári tanár úr, dékán úr fontosnak tartotta, hogy a hivatalos tárgyalások után szükre szabott idejében velünk, diákokkal is találkozhasson és beszélgessen. Sokat jelentett ez nekünk akkor.

4.6. Középiskolai tanárnak készültem, de másként alakult az életem és a pályaválasztásom. Az államvizsga elött engem is, mint ahogy akkoriban többeket elküldött tanár úr a Nyelvtudományi Intézetbe: nézzek körül, keressem föl B. Lőrinczy Éva tanárnőt, ismerkedjek meg a tájszótár munkálataival, ott mindig szükség van új 
munkatársakra. (Nocsak, visszatér az életembe az iromba?) A „látogatás” az intézetbe tartósnak bizonyult, előbb - ahogy akkoriban lehetett - szerződéses részfoglalkozású ügyintézői, majd teljes óraszámú (segédmunkatársi, munkatársi, főmunkatársi) munkaviszony lett belöle, amely mindmáig tart. Igaz, nem a tájszótárhoz kerültem, mert akkor ott éppen „felvételi zárlat” volt, és Lőrinczy Éva tanárnő tovább küldött Grétsy tanár úrhoz a nyelvmüvelő osztály vezetőjéhez. Megtapasztaltam, hogy ott is „jó ajánlás” volt Szathmári tanár úr diákjának lenni.

Nyelvmüveléssel én addig nem foglalkoztam. Próbacikkeket kellett írnom, rövid, érdekes nyelvmüvelő cikkeket, az Élet és Tudomány nyelvi rovatába. Új, ismeretlen feladat volt ez számomra, és megint csak kisegített az iromba meg a nyelvészeti, a stilisztikai szemináriumokon szerzett tudásom, tapasztalatom. Mindez 1976-ban volt, az intézet helye, az osztály neve, összetétele közben többször is változott. Máig megmaradt része, a Nyelvmüvelő és nyelvi tanácsadó kutatócsoport (a Nyelvtechnológiai és alkalmazott nyelvészeti osztályhoz tartozva) látja el az intézeti nyelvi tanácsadó szolgálatot. És - ha nem is a pályám elején, de tanár is lehettem, a Károli Gáspár Református Egyetemen stilisztikát, jelentéstant, retorikát, helyesírást, nyelvmüvelést, írói nyelvmüvelést taníthatok mind a mai napig.

4.7. Most, ahogy felidéztem egyetemi éveimet, pályakezdésemet, látom, hogy a stilisztika mint kutatási terület és Szathmári tanár úr pedagógiája egész pályámra nézve meghatározó volt. A már említett szakdolgozat, Az elmúlás metaforái Sinka költészetében, majd az egyetemi doktori dolgozat, a Nyelvi épitkezés Sinka István balladáiban voltak az első állomások, témavezetőm mindkét esetben Szathmári tanár úr volt. A vizsgákra, a doktori vizsgára, az egyes résztárgyakra (stilisztika, jelentéstan, 20. századi erdélyi irodalom, filozófia) nagyon föl kellett készülni. Szathmári tanár úr köztudottan igényes és szigorú volt. A tárgyi tudás, a felkészülés az alap, a minimum, mondta gyakran, de be is kell ám tudni mutatni a tudást, a tájékozottságot! Nem szabad hallgatni, nem lehet megijedni a váratlan kérdésektől sem, és beszélni, beszélni, beszélni, mondta jó tanácsként az ilyen alkalmak elött.

Később évek, évtizedek követték egymást. Család, munka, újabb és újabb feladatok, de érdeklődési és kutatási területemként megmaradt a stilisztika, a nyelvmüveléssel kiegészülve. Ebből a „találkozásból” lett későbbi kedves témaköröm és kandidátusi disszertációm, az írói nyelvmüvelés 20. századi ágainak és sajátosságainak kutatása. A bizottság elnöke, Szathmári tanár úr külön figyelemmel köszöntötte a nyilvános védésen megjelent családomat, iskolás és óvodás gyermekeimet, akiknek így ez az alkalom hosszú időre szóló, jó élményt jelentett. Szathmári tanár úr a szó legnemesebb értelmében, mai szóval családbarát volt. Tudta, és mindig mondta is, hogy a család a legfontosabb, hogy a család az a hely, ahol az ember otthon lehet, ahova hazamehet.

4.8. Ez neki magának is nagyon fontos volt, konkrét és tágabb értelemben is: ,„Hazamenni« mindig Kisújszállást jelentette nekem és családomnak is. Mennyi melegség, mennyi biztonság és erő van ebben a kedves igekötőben: haza-. Azt szimbolizálja, hogy tartozunk valahová, hogy számon tartanak bennünket, hogy a gyökereink oda- 
kötnek egy meghatározott helyhez. Nyilván nem véletlenül alakult haza határozószavunk, illetve igekötőnk az élet alapvető feltételét megtestesítő ház szóból. És nem véletlenül vette fel ez a szó mint fönév annak az országnak, népközösségnek a jelentését, amelyhez ki-ki tartozik" - olvassuk a Szülöföldem, a Nagykunság címü írásában, A szükebb és a tágabb haza nyelve kötetének bevezetö tanulmányában (Szathmári 2005: 15).

Igen, ezt is láttuk Szathmári tanár úrtól, a szülöföldhöz, a miénkhez, a sajátunkhoz való ragaszkodást, az önazonosság tartást adó, megtartó erejét. Láttuk, hogy a nép nyelve (és zenei anyanyelve) a legősibb forrása, a legarchaikusabb rétege az adott közösség nyelvének és közös emlékezetének, az irodalmának, sőt az egész kultúrájának. A népnyelv ezért fontos, ezért érdemes ismerni, ezért becsülje meg az, aki egyik vagy másik változatába, nyelvjárásába beleszületett. Mert ez létünk kerete, visszatérve az előbbi metaforához, ez az ember lelki és szellemi háza. Tudjuk a lét és idő filozófusától, Heideggertől, hogy a nyelv a lét háza. Amíg megvan a ház, addig élhet benne a ház népe is. A magyar nép a magyar nyelvben.

4.9. A stilisztika meg a retorika pedig - tudjuk a retorika elméletéből és hagyományából - ezt a létet szolgálja. Azzal, hogy gondolkodni és beszélni tanít, ahogy Babits Mihály fogalmazta meg Irodalmi nevelés címü esszéjében. A tudománynak, a nyelvtudománynak is ez a lényege, a tudósnak, a nyelvtudósnak is ez a feladata: gondolkodni és beszélni tanít - müveivel és személyiségével, hatásával. Ezt láttuk, ezt tanulhattuk Szathmári tanár úrtól is. Munkáján, példáján keresztül, és sokszor az olyan apró részleteken át is, ahogy verselemzésein keresztül bemutatta, hogy a megértés és a megértetés a legfontosabb. Kányádi Sándor szavait idézte: aki megért / és megértet / egy népet megéltet, és megmutatta, hogy a világos gondolat és a világos beszéd, és persze itt a költészet, az irodalom, jó a léleknek, és megtartó erejü, megtart egyént, családot, közösséget, magyarságot.

4.10. Hogy megmaradhatott és megerősödhetett számomra a stilisztika mint kutatási terület, az igen nagy mértékben annak a szakmai és emberi háttérnek köszönhetö, amelyet a Stíluskutató csoport munkaközössége jelentett számomra, mondhatom többes számban is, számunkra, pályatársaimmal együtt. Ez a mühely 1970-től müködik (folytatólagosan jelenleg is) az ELTE Mai Magyar Nyelvészeti Tanszékén. Előbb a tanszék stilisztikával foglalkozó akkori munkatársainak részvételével jött létre, majd kiegészült a későbbi tanszéki oktatókkal. 1979-től pedig fokozatosan kibővült a Nyelvtudományi Intézet stilisztikával foglalkozó munkatársaival, a hazai, majd a határon túli egyetemek, föiskolák stilisztikaoktatóival és -kutatóival. A Szathmári tanár úr alapította és négy évtizeden át az általa vezetett Stíluskutató csoport létével és eredményeivel beírta magát a magyar és a nemzetközi nyelvtudomány történetébe. Életre hívása és életben tartása kiemelkedő és szinte egyedülálló szakmai és pedagógiai teljesítmény volt a 20 . századi „rohanó” világban.

A csoport vezetőjéből, tagjaiból és a rendszeresen meghívott vendégekből álló, szerves rész-egész viszonyrendszerben, mai szóval „hálózatban” minden egyes rész, minden egyes tag fontos volt, mindenki megtalálhatta és magas színvonalon végez- 
hette el a maga feladatát. Ha ezt jól tette, a közöset, az egészet is építette, az egészből pedig a részek is gyarapodtak. Kandidátusi, nagydoktori értekezések, később PhD-disszertációk, akadémiai doktori értekezések, habilitációs dolgozatok születtek a legkülönfélébb stilisztikai témákból, és kutatói, tanári életpályák teljesedtek ki. Az eredményeket itt nincs mód részletezni, csak jelzésként utalok néhány közös munkára: Tanulmányok a századforduló stílustörekvéseiröl (1989), Hol tart ma a stilisztika (1996), Stilisztika és gyakorlat (1998). Később az Alakzatok világa sorozat füzetei, amelyek előkészítették a szintézist, a 2008-ban megjelent Alakzatlexikont, az akkor több mint harminctagú munkaközösség legjelentősebb eredményét. A munkálat vezetője, szervezője, a kötet főszerkesztője: Szathmári István.

\section{Befejezés}

Szathmári István nyelvtudós, pontosabban nyelv- és irodalomtudós volt. Stilisztikatörténetet írt, nyelvi és irodalmi tablókat készített a magyarság évszázadaiból, eleinktől kezdve máig: A magyar nyelv tudatosodásának útja a Halotti beszédtöl a felvilágosodás kezdetéig, Szenczi Molnár Albert és irodalmi nyelvünk, A reformáció és benne a Vizsolyi Biblia nyelvi hatása, Kazinczy és irodalmi nyelvünk, Vörösmarty reprezentativ verse, „A vén cigány”, Alakzatok Márai Sándor Halotti beszéd címü versében. Ha ezeket az írásait olvassuk, megtapasztaljuk azt az egységet, azt az egész-séget, amely valaha természetes volt nyelv és irodalom, nyelv- és irodalomtudomány viszonyában. Ezzel is tanított, szemléletet formált, kapcsolatot, átjárást, hidat teremtett a „,két testvértudomány” között. Hogy sikeresen, ezt magam is láthattam, amikor Tanár úr, először nyelvészként, az irodalomtudományi Faludi Ferenc alkotói díjat átvehette (Heltainé Nagy 2012).

Szathmári István professzor volt, tudós és tanár. Az egyetemes és a magyar nyelvtudomány, a stilisztika, a retorika művelője, a magyar irodalmi nyelv, a nyelvi norma történetének és elméletének komplex látásmódú, interdiszciplináris szemléletü kutatója.

Szathmári István kiváló pedagógus, igazi, nagybetüs Tanár volt. Tudást, módszert, szemléletet, erkölcsi tartást és emberi törődést tanulhattunk töle. És persze szaktudást is, konkrétumokat, a stilisztika elméletét és gyakorlatát, a tudomány müvelésének a fontosságát, ezáltal pedig végső soron az anyanyelvi müvelődés, a magyarság megmaradásának szolgálatát. Erre mutatott példát, erre (is) tanított. Ezt próbáltam és próbálom én is megérteni és megértetni, amennyire tudom, és a magam módján és helyén továbbadni olvasóimnak, hallgatóimnak, gyermekeimnek, unokáimnak.

Szathmári tanár úr példát adott a tudomány és az ember iránti nyitottságra, igényt a szintézisre, a munka, a hivatás megbecsülésére, szeretetére. Olyan harmóniát, megelégedettséget és békességet sugárzott, amelyet a hivatás öröme, a szolgálat felelössége teremthet meg, de csak a hüség, a szeretet, a hit és az engedelmesség tarthat meg, a földi élet olyan időbeli teljességében, amely Szathmári tanár úrnak megadatott. Ez is hatott, ez is hat ránk, talán még a stilisztikát is felülmúló hatással. 


\section{SZAKIRODALOM}

Balázs Géza 2005. Szathmári István 80 éves. Magyar Nyelv 101: 120-2.

Heltainé Nagy Erzsébet 2012. Laudáció Szathmári Istvánról a Faludi Ferenc Alkotói Díj átadása alkalmából. Magyar Nyelvőr 136: 240-4.

Keszler Borbála 1995. Szathmári István 70 éves. In: Laczkó Krisztina (szerk.): Emlékkönyv Szathmári István 70. születésnapjára. ELTE, Budapest, 9-11.

Szathmári István 1991. A nyelvészetröl egyes szám első személyben. ELTE, Budapest, 241-9.

Szathmári István 1993. Szabó Pál a nevekröl, a névdivatról. Névtani Értesitő 15: 293-5.

Szathmári István 1998. Vallomása pályájáról. Magyar Nyelvész Pályaképek és önvallomások 44. ELTE Fonetikai Tanszék, Budapest.

Szathmári István 1999. A kisújszállási nyelvjárásról, a kisújszállásiak beszédéről. Magyar Nyelvjárások XXXVII: 413-8.

Szathmári István 2002. Utószó. Illyés Gyuláról és a kötetről. In: Illyés Gyula: A törzs szavai. Írások az anyanyelvröl. Nap Kiadó, Budapest, 241-50.

Szathmári István 2005a. A szükebb és tágabb haza nyelve - Népnyelvi és irodalmi nyelvi tanulmányok. Szerk. Tátrai Szilárd - Tolcsvai Nagy Gábor. ETE BTK Mai Magyar Nyelvi Tanszék, Budapest.

Szathmári István 2005b. Szülőföldem, a Nagykunság. In: Tátrai Szilárd - Tolcsvai Nagy Gábor (szerk.): A szükebb és tágabb haza nyelve - Népnyelvi és irodalmi nyelvi tanulmányok. ELTE BTK Mai Magyar Nyelvi Tanszék, Budapest, 15-24.

Szathmári István 2015. A Magyar Nyelvtudományi Társaság története (1904-2005). Tinta Könyvkiadó, Budapest.

Szathmári István 2018. Dayka Gábornak Aorthographia címet kapott, kéziratban fennmaradt magyar nyelvü, nyelvészeti jellegü írásáról. Magyar Nyelvőr 142: 125-36.

Szathmári István 2019. Dayka Gábor Grammatikai feljegyzések címü, kéziratban fennmaradt, magyar nyelvü, nyelvészeti jellegü írásáról. Magyar Nyelvör 143: 47-57.

Heltainé Nagy Erzsébet

tudományos fömunkatárs egyetemi docens

ELKH Nyelvtudományi Intézet -

KRE BTK Magyar Nyelvtudományi Tanszék

https://orcid.org/0000-0002-6899-8685 